\title{
MÜŞTERİ MEMNUNIYYETI SAĞLAMA VE MÜŞTERİ SADAKAT PROGRAMLARININ MÜŞTERIYYİ ELDE TUTMA ÜZERİNDEKİ ETKİSİ: GİRNE'DE BEŞ YILDIZLI OTELLER ÖRNEĞİ
}

\author{
Mehmet Necati CIZRELIOĞGLLARI ${ }^{1}$ \\ Rukiye KİLİLI 2 \\ Mete GİRGEN 3
}

\author{
Received Date (Başvuru Tarihi): \\ Accepted Date (Kabul Tarihi): \\ Published Date (Yayın Tarihi):
}

$31 / 03 / 2020$

$20 / 05 / 2020$

$25 / 06 / 2020$

Çalıșmada ilk yazar Sorumlu Yazar (Corresponding Author) rolündedir.

\begin{abstract}
$\ddot{O Z Z}$
Günümüzde gün geçtikçe artan yoğun rekabetçi ortamda otel müşterileri Anahtar Kelimeler:

Müşteri Memnuniyeti

Müşteri Sadakati

Müşteriyi Elde Tutma

Sadakat Programlarn

Kuzey Kibris

JEL Kodlart:

J28

J81

L83

Z32

memnuniyetini sağlamak ve elde tutmak gittikçe güç duruma gelmektedir. Bu durum otel işletmeler ile müşteriler arasında uzun süreli ilişkilerin oluşmasına zemin hazırlayarak, müşteri memnuniyetini săglamak ve müşterileri elde tutmak için yeni arayışlara itmiştir. Müşteri memnuniyeti ve müşteri sadakati otel işletmeler için müşteriyi elde tutmak için önemli kavramlardır. Müşteriyi memnun edebilen otel ve onlarn elde tutabilen işletmeler sadakat programlarm uygulayarak, varliklarm devam ettirebilmekte ve karlkların istikrarlı bir duruma getirebilmektedir. Bu bağlamda bu çalışmanın amacl, Kuzey Kıbrıs'ta Girne Bölgesinde faaliyet gösteren 5 yıldızl otelde konaklayan müşterilerin memnuniyetini artırmak ve müşterileri elde tutmak için müşteri sadakat programlan ile arasındaki ilişkiyi incelemektir. Araştırma yöntemi, kolayda örnekleme modeli doğrultusunda Girne'de faaliyet gösteren 22 otelden 12'sine ulaşılarak ve 360 müşteriden veri toplanarak, SPSS 22. İstatiksel programıyla analizi yapıldı. Araştırma sonucunda, müşteri memnuniyeti ve sadakat programlarmın bir müş̧erinin sadakatini artırabilecek önemli etkenler olduğu ve bu faktörlerin müşteriyi elde tutmada önemli unsur olduğu sonucuna varılmıştır. Araştırmalar, otel işletmelerin müşteriyi elde tutmak için daha iyi ve daha fazla müşteri memnuniyeti ve müşteri sadakati sağlamak adına hizmetlerin kalitesini iyileştirmeye odaklanması ve sadakat programların uygulaması gerektiğini göstermektedir. Bu çalışmanın sonuçları, otel ve konaklama sektörü gelişimine daha fazla fayda sağlayacak ve ileride farklı sektörler üzerinde yapılması planlanan çalışmalara yol gösterecektir.
\end{abstract}

$\begin{array}{llllll}\text { Keywords: } & \text { Customer Satisfaction } & \text { Customer Loyalty } & \text { Customer Retention } & \text { Loyalty Programs } & \text { Nothern Cyprus } \\ \text { JEL Codes: } & J 28 & \text { J81 } & \text { L83 } & \text { Z32 }\end{array}$

\footnotetext{
${ }^{1}$ Yrd. Doç. Dr., Kıbrıs İlim Üniversitesi, mehmetcizreliogullar@csu.edu.tr,

2 Doç. Dr., Kıbrıs İlim Üniversitesi, rukiyekilili@csu.edu.tr,

${ }^{3}$ Dr., Kıbrıs İlim Üniversitesi, metegirgen@csu.edu.tr,
}

https:// orcid.org/0000-0002-9884-6084 https:// orcid.org/0000-0002-2049-6432 https:// orcid.org/0000-0003-2709-5639 


\section{EXTENDED ABSTRACT}

\section{THE EFFECT OF CUSTOMER SATISFACTION AND CUSTOMER LOYALTY PROGRAMS ON CUSTOMER RETENTION: THE EXAMPLE OF FIVE STAR HOTELS IN KYRENIA}

\section{LITERATURE}

\subsection{RESEARCH SUBJECT}

Today, it is becoming increasingly difficult to ensure and retain hotel customers in an intensely competitive environment. In this case, it pushes hotel businesses to establish long-term relationships between customers and hotel businesses, new quests to ensure customer satisfaction and retain customers. Hotel businesses have been in various searches to establish long-term relationships with their customers, ensure customer satisfaction and retain customers.

\subsection{RESEARCH PURPOSE AND IMPORTANCE}

The purpose of this study is to examine the relationship between customer loyalty programs in order to increase the satisfaction of the customers staying in the 5-star hotel operating in the Kyrenia Region in Northern Cyprus and to retain the customers. The importance of customer satisfaction, customer loyalty and loyalty programs is becoming more and more important in hotel businesses and the quality of service provided by hotel businesses, which is an important factor in the competitive environment, is also increasing significantly.

\subsection{CONTRIBUTION of the ARTICLE to the LITERATURE}

This research concludes that loyalty programs are important to retain and maintain customer satisfaction, but are not very much appreciated in hospitality or other industries, and therefore new research can be done on how to offer better loyalty programs for valued customers in these sectors.

\section{DESIGN AND METHOD}

\subsection{RESEARCH TYPE}

Descriptive research type was used in this research. Hypotheses were determined. Because the studies for developing a hypothesis have the characteristics of descriptive research.

\subsection{DATA COLLECTION METHOD}

This research was carried out by using a simple sampling method from the non-random sampling technique for customers staying in a 5-star hotel operating in the Kyrenia region. There are a total of 153 hotels in Northern Cyprus, 22 of which are in the 5-star hotel group.

\subsection{QUANTITATIVE/ QUALITATIVE ANALYSIS}

The method used was the quantitative method. SPSS version 22. statistical program was used to analyze research data. 


\subsection{RESEARCH MODEL}

In accordance with the model of the study, the relationships between customer satisfaction and loyalty have been examined, the purpose of the study and hypotheses have been determined in order for the managers who apply loyalty programs for the customers of 12 five-star hotels operating in Kyrenia to retain the customer.

\subsection{RESEARCH HYPOTHESES}

$\mathrm{H}_{1}$ : Loyalty programs have a significant effect on customer retention.

$H_{1 a}$ : There is a significant relationship between satisfaction with customer loyalty programs and customer retention.

$H_{1 b}$ : There is a significant relationship between trust in customer loyalty programs and customer retention.

$\mathrm{H}_{2}$ : There is a significant relationship between customer satisfaction and customer retention in hotel businesses.

$\mathrm{H}_{3}$ : There is a significant relationship between customer loyalty and customer retention.

\section{FINDINGS AND DISCUSSION}

\subsection{FINDINGS as a RESULT of ANALYSIS}

In this study, Kaiser Meyer Olkin (KMO) and Barlett test were used to test and Varimax method was used to organize the questions consistent in the data set to make the study manageable and to determine whether the data set was suitable for factor analysis. Findings of the research show that loyalty programs are the most important means of retaining customers, directly affecting customer loyalty and increasing customer satisfaction. Loyalty programs enable the customer to retain after influencing customer satisfaction and loyalty.

\subsection{HYPOTHESIS TEST RESULTS}

As a result of the research, it has been concluded that customer satisfaction and loyalty programs are important factors that can increase a customer loyalty and these factors are important factors in keeping the customer. When approached from a different perspective, all hypotheses were accepted because the $\mathrm{p}$ value was less than $5 \%$.

\subsection{DISCUSSING the FINDINGS with the LITERATURE}

According to Wijaya (2005); loyalty programs applied increase customer satisfaction and turn them into loyal customer potential. According to Singh and Khan (2012), keeping the customer is the factor that ensures the highest level of profit for the business, this is the customer satisfaction and loyalty that provides this factor. According to Barutçugil (2009) and Lin and Wu (2011), customer satisfaction has a positive effect on customer loyalty and leads to customer retention. Furthermore, Rashid et al. (2015) and Verhoef (2003) stated that improved customer loyalty programs will keep customers in the company, increase customer satisfaction and affect customer retention positively.

\section{CONCLUSION, RECOMMENDATION AND LIMITATIONS}

\subsection{RESULTS of the ARTICLE}

As a result of the research, it has been concluded that customer satisfaction and loyalty programs are important factors that can increase a customer loyalty and these factors are important factors in keeping the customer. According to the data obtained from the literature review; loyalty programs applied increase customer satisfaction and turn them into potential loyal customer; Retaining the customer is the factor that maximizes the profit of the business, this is the customer satisfaction and loyalty that provides this factor; Customer satisfaction has a positive effect on customer loyalty and leads to 
customer retention; Improved customer loyalty programs will increase customer satisfaction and positively affect customer retention by keeping customers within the company. In addition, hotel businesses should focus on loyalty programs that provide a sense of belonging to the customer, strengthen emotional ties with the business and ensure good communication with the customer.

\subsection{SUGGESTIONS BASED on RESULTS}

Hotel businesses should focus on loyalty programs that provide a sense of belonging to the customer, strengthen emotional ties with the business and ensure good communication with the customer.

\subsection{LIMITATIONS of the ARTICLE}

Future studies should support this view with richer research structures, as it seems that loyalty programs have failed to achieve consensus on whether customer loyalty creates customer satisfaction. Loyalty programs are important to retain and maintain customer satisfaction, but are not very much appreciated in hospitality or other industries, and therefore new research can be done on how to offer better loyalty programs for valued customers in these sectors. 


\section{GİRIŞ}

Pazarlama alanında, müşteri sadakat programları hem müşteriler hem de şirketler için faydalı olmasından dolayı güçlü araçlardır. Bu programları uygulayan şirketler, yeni müşteri profilleri oluşturmaktan ziyade mevcut olan müşterilere daha kolay bir şekilde ulaşmaları yönünden daha akıllı bir yol izlemektedir (Singh ve Imran, 2012). Günümüzde müşterilerin ve şirketlerin etkileşimi çok önemli hale gelmektedir. $\mathrm{Bu}$ ilişki müşterileri kısa vadede elde tutmayı değil, uzun vadede tutmayı amaçlamaktadır (Çamlı, 2010). Bu bağlamda, bu ilişki pazarlamasının ana fikri sadakat programları oluşturmak ve uzun vadede rekabet ortamını uygun hale getirmektir. Müşteriler, şirketlerle güçlü bir bağa sahip olduklarında, herhangi bir pazarın ürününü takip etmez ve şirketlerin tekliflerini değerlendirmezler (Uyar, 2019). Bu durum, pazar rekabetinde müşteri sadakatinin ve programlarının önemini göstermektedir. Konaklama sektöründe teknolojinin gelişimine bağlı olarak birçok otel markası (\%41) ve seyahat şirketleri (\%57) farklı türlerde sadakat programları kullanmaktadır (Magatef ve Tomalieh, 2015). Şirketler, müşterilerinin davranışlarına göre onları ödüllendirerek, müşteri sadakati oluşturmak için sadakat programları tasarlamaktadır (Ray, 2015). Otel sektöründe müşteriyi elde tutmak için, öncelikle onların ihtiyaçlarını ve isteklerini anlamak son derece önem taşımaktadır. Müşteri tercihi, müşteri etkileşimlerine dayalı bazı verilerle anlaşılabilmekte ve sadakat programını kullanan çok az sayıda otel bulunmaktadır (Hennig-Thurau ve Klee, 1997). Bu bağlamda, Girne'de bu sadakat programlarını aktif olarak kullanan az sayıda 5 yıldızlı otel bulunmaktadır. Bu oteller, işletmelerin sadakat programlarıyla başarılı olup olmadıklarını anlamak için sadakat programlarının anketlerini analiz etmekte, internet ve sosyal medya platformlarını taramaktadırlar. Otel misafirlerinin neler hissettikleri, paylaştıkları, önerdikleri ve oteldeki duyguları, deneyimleri hakkında ne düşündüklerini bilmek önemli bir unsur olmasından dolayı sadakat programlarının hedeflenen ödüller ile tasarlanması, değere göre farklı müşteri profillerini karşılaması işletmeler açısından müşteriyi elde tutmada son derece önemlidir. Bu ödüllerden biri olan katman sistem ödülü (Gümüş, Altın ve Platin), müşterilerin harcama ve satın alma düzeylerine dayanır ve konukların daha yüksek harcama yapmasını teşvik etmektedir (Ray, 2015; Magatef ve Tomalieh, 2015; Özgür ve Günaydın, 2010). Bununla 
birlikte bu sistem, sadakat programlarını daha hedefli ödüller ile tasarlar, değerlerine göre farklı üye gruplarına göre farklılık göstermesi ve daha yüksek harcama seviyelerini teşvik etmek için en iyi müşterileri ödüllendirerek daha yüksek müşteri değeri katmanlarında daha fazla değer sağlamaktadır (Magatef ve Tomalieh, 2015; Onaran vd., 2013).

Bu çalışma da Girne'de faaliyette olan 5 yıldızlı otel işletmelerinde konaklayan müşterilerin memnuniyetinin sağlanması ve sadakatinin artması için sadakat programlarının uygulanması ve sadakat programlarının müşteriyi elde tutma üzerindeki etkisi incelenmiştir. Bu bağlamda, bu çalışma pazarlama çabalarının özgünlük ile karakterize edilmesi ve farklı türden beklentilerin anlaşılması gerektiğini önermektedir. Ayrıca bu çalışma, 5 yıldızlı oteller tarafından sunulan sadakat programlarının pazarda rekabet avantajı yaratmada ve marka sadakati ve itibarını artırmada güçlü bir etkiye sahip olduğunu göstermektedir. Bunun yanında, oteller tarafından sağlanan sadakat programlarının müşteriyi elde tutma üzerinde olumlu bir etkiye yol açtığını da göstermektedir. Mevcut çalışma, araştırmacılarının müşteri sadakat programlarının önemini gösteren daha fazla çalışma yapmaya teşvik etmek için literatürün gelişmesine katkı koyacaktır.

\section{KAVRAMSAL ÇERÇEVE}

\subsection{Müşteri Memnuniyeti ve Sadakati}

Müşteri memnuniyeti, müşterilerin beklenen hizmete olan mutluluğu olarak düşünülebilir (Onaran vd., 2013). Müşteri memnuniyeti, hizmet alan müşterilerin memnun olması veya bekledikleri turizm ürünleriyle tatmin olduklarında, onları iyi hissettiren psikolojik kavramdır. Bu olgu, onların arzularını iyi bir şekilde tatmin hissetmelerini sağlamaktadır (Pizam ve Ellis, 2000). Son zamanlarda, müşteri memnuniyetinin tanımı, duygusal tepkiler olarak kabul edilmektedir (Bağcı, 2018). Giesse ve Cote'ye (2002) göre, müşteri memnuniyeti, müşteri memnuniyetine odaklanmayı sağlayan nesneleri tanımlar ve kurumların performansını belirli standartlara göre karşılaştırılmasını gerektirir. Farklı bir perspektiften incelendiğinde, müşteri memnuniyetinin birçok farklı tanımı mevcuttur, yazarların çoğu bunu müşteri ve memnuniyet tanımlarıyla ilgili olarak farklı fikirleri paylaşarak tanımlamaktadır. 
Nykiel (2005), müşteri memnuniyeti kavramını şu formülle göstermektedir: Müşteri Memnuniyeti $=$ Müşteri Beklentileri + Algılanan Hizmet ve Değerdir. Müşteri memnuniyeti duygusal ve bilişsel bir yanıttır ve hizmet kalitesi ile yakından ilişkilidir. Müşteriler, algılanan hizmetlerden memnun kalmazsa şirketler çözüm bulmalı ve müşterinin beklentisini karşılamalıdır (Öztürk ve Seyhan, 2005). Ancak yapılan çalışmalar incelendiğinde, müşteri beklenti düzeyinin artması, memnuniyet düzeyini düşürmektedir (Kahraman vd., 2010; Şahin ve Şen, 2017). Bu bilgiler 1şı̆̆ında, turizm sektöründeki, hizmet hatalarını diğer sektörlere göre düzeltmek daha zordur (Bahar ve Kozak, 2005). Farklı bir perspektiften incelendiğinde; Gopalkrishnan'a (2011) göre, müşteri aldığı hizmetten ve herhangi bir ürünü kullanmaktan memnunsa, ayrıca ürünün kalitesi performansıyla iyi bir şekilde eşleşiyorsa, müşterinin mutluluk seviyesi artar. Eğer müşteri hizmetten memnun kalmışsa, müşteri sadakat gösterir. Müşteri üründen ve hizmetten memnun kalmazsa, sadakatlerinin garanti edilmediği anlamına da gelebilir. Dolayısıyla, müşteri memnuniyeti müşteri sadakatiyle doğru orantılıdır, müşteri memnun olursa sadakati artar. Bundan dolayı, işletmeler, müşterileriyle uzun vadeli karlı bir ilişki kurmalı ve pazardaki marka imajını geliştirmek için müşteri sadakat programlarına özel olarak odaklanmalıdır (Tu, 2012; Gopalkrishnan, 2011; Valenzuela ve Vásquez-Párraga, 2006; Wu ve Chen, 2012).

\subsection{Müşteri Elde Tutma}

Müşteriyi elde tutma, işletmelerin yüksek kalitede hizmet verme ile mükemmel bir müşteri deneyimi sağlayarak müşterilerini korumak için harcadıkları çabadır (Roking, 2005). Ayrıca, işletmelerin kar etmesini ve başarılı olmasını sağlayan anahtar kelimedir (Gümüş, 2014). İşletmelerin en değerli müşterileri elinde tutmasına yardımcı olan müşteri sadakati, müşteri ilişkilerinin gelişimini olumlu yönde etkilemektedir (Singh ve Imran, 2012). Şirketler, müşteri ilişkilerini geliştirmek için iş uygulamalarını uygulayarak ve her müşterinin profilini belirleyerek müşteri değerini artıran yolları belirlemek adına pazarlama yöntemlerini ve iletişim teknolojilerini kullanmaktadırlar (Reinartz vd., 2004). Müşteri sadakat programları yeni müşteriyi mevcut müşteriye dönüştürmeyi amaçlamaktadır. Yüksek maliyet faktörü, her geçen gün müşteri kaybının artmasına neden olmaktadır (Liu, 2007). İşletmeler, her zaman yeni müşterilerini, sadık müşterilerine göre belirlemek ve sadık müşterilerini elde 
tutmak için stratejilerini planlarken yeni teknikler aramaya çalışırlar (Çoban, 2005). Hizmet kalitesi, müşteriyi elde tutmada en önemli unsurdur. Müşteriyi elde tutmak, işletmenin kârının en yüksek düzeye çıkmasını sağlayan faktördür ve rekabetçi pazarda iyi bir üne sahiptir (Singh ve Khan, 2012). Müşteriyi elde tutma, müşterilerin tekrar satın alınmasıyla ilgilidir. Müşteri memnuniyeti, müşteri sadakati üzerinde olumlu bir etkiye sahiptir ve müşteriyi elde tutmaya neden olur (Barutçugil, 2009; Lin ve $\mathrm{Wu}, 2011)$. Ayrıca, memnuniyet ve mutluluk arasında önemli bir köprü görevi üstlenerek müşteriyi elde tutmaya yardımcı olmaktadır (Özkaya, 2002). Başka bir açıdan bakıldığında, işletmeler derecelendirme hususlarına dikkat ederek müşterileri elde tutmak için yöntemler geliştirmektedir (Ziethaml vd., 1993). Ancak, bu yöntemle, işletmeden memnun olan müşterilerin \%100 işletmeye sadık kalacağ1 garanti edilmemektedir (Gronholdt vd., 2000; Gagliano ve Haithcote, 1994). Bu bağlamda, müşterileri kaybetmenin yüksek maliyeti her geçen gün arttığı için şirketler sadık müşterilerini elde tutmak için yeni teknikler ve yöntemler aramaktadır (Nili ve Keramati, 2012). Hizmet faktörü, müşteriyi elde tutmak için önemli bir unsur olmuştur. Yeni araştırmalar, hizmet rolünün her zamankinden daha kritik süreçte olduğunu ve gelecekte de yeni yöntemler keşfetmenin devam edeceğini göstermektedir. (Potter -Brotman, 1994; Selvi ve Ercan, 2006).

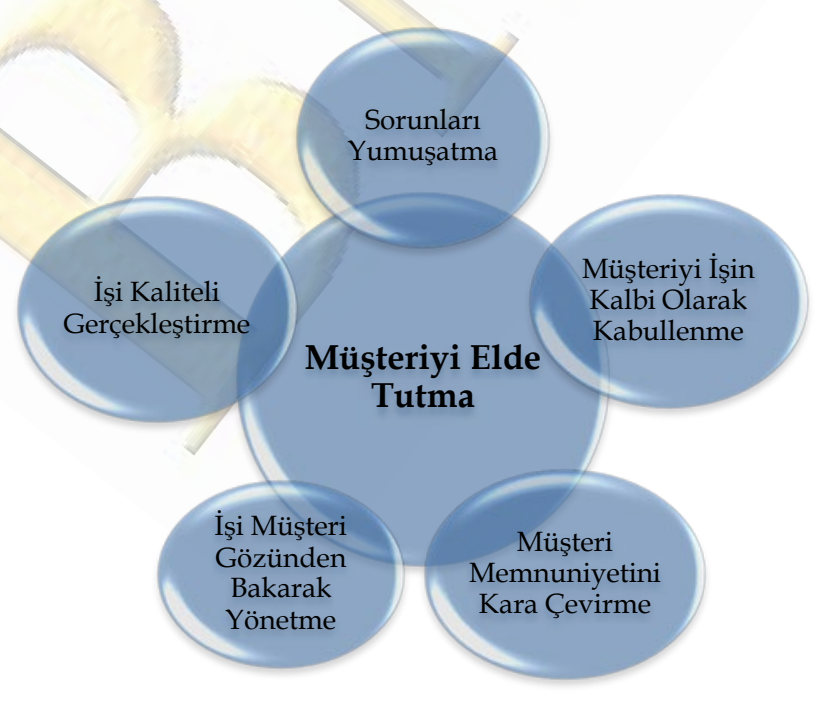

Şekil 1. Müşteriyi Elde Tutma İlkeleri

Kaynak: Odabaşı, 2000: 113-114; Gümüş, 2014: 43 
Şekil 1'e bakıldığında, müşteriyi elde tutma ilkelerini görmekteyiz. İşi kaliteli olarak gerçekleştirme, müşteriyi işin kalbi olarak görme, müşteri memnuniyetini kara çevirme, işi müşteri gözünden bakarak görme ve yaşanılan sorunları yumuşatma gibi ilkeler müşteriyi elde tutmak için temel prensiplerdir.

\subsection{Sadakat Programları}

Müşteri sadakat programları, müşterilerin işte faydalı olan davranışlarını ödüllendiren ve teşvik eden yapılandırılmış pazarlama programlarıdır. $\mathrm{Bu}$ programlar, işletmelerin harcamalarını artırmak için müşterilere sunulmaktadır (Wijaya, 2005). Müşterilere özel indirim kuponları ve biletleri veya ücretsiz ürünler verebilmektedir. Müşteriler genellikle kişisel bilgilerini (e-posta, telefon numarası veya adres olarak) işe kaydetmekte ve bu tür bilgiler sayesinde müşterilere kolay bir şekilde iletişim sağlanmaktadır. Ayrıca, bilgiler, şirketin kampanyaları hakkında olabilmektedir (Peiguss, 2012). Müşteri sadakat programları, zaman içerisinde müşterilerin toplam harcamalara dayanarak, pazardaki bazı kampanyalarla fayda ve avantajlar sağlayarak bir teşvik olarak çalışabilmektedir (Yi ve Jeon, 2003). Müşteri sadakat programları, tüketicilerin kısa vadeli karar vermekten ziyade, uzun vadeli karar almaya geçişi teşvik edici faktörlerdir. İşletmelere bağlı olan müşterilere, sınıf düzeyinde artış / yükseltme, ücretsiz hizmetler veya diğger mal, ürün veya hizmetlerin takası olarak değişebilen bazı hususlar verilebilmektedir (Stathopoulou ve Balabanis, 2016). Örnek verecek olursak, Almanya ve ABD'de müşteri sadakat programlarının kullanımı yıllar önce fiyat yarışmalarıyla başladı. American Airlines, dünyada 1981 yılında müşteri sadakat programları kullanan ilk kuruluştur (Berman, 2006). Bundan sonra, birçok otel, seyahat acentesi, tur operatörü ve nakliye şirketi, turizm işletmeleri için bir trend haline gelmiştir (Lacey ve Sneath, 2006). Birçok sektör, müşteriler için sadakat programları uyguladı. Müşterileri kazanmak ve daha fazla insana ulaşmak için bazı reklamlar ve taktikler uyguladı ve geliştirdi (Artuğer, 2011). Sadakat programları, müşterilerini memnun etmek, müşteri sadakatini ve müşteriyi elde tutmak için müşteri ilişkileri stratejisinin bir parçası olarak kabul edilmektedir (Selnes, 1993). Sadakat Pazarlamacıları Birliği'ne göre sadakat programlarını kullanan dört müşteri türü vardır (Lee vd., 2014). \%100 sadık olan müşteriler, ürün veya hizmetin hafif alıcıları olma eğilimindedir. Bu ampirik gerçekler, \%100 sadık müşterilerden 
oluşan büyük bir grup oluşturmak için bir sadakat pazarlama programı kullanma konusunda çok hevesli olmayı zorlaştırmaktadır (Uncles vd., 1995).

- Asla sadık olmayan müşteriler: Sadakat programlarından ve ödül teşviklerinden hiçbir şekilde etkilenmeyen müşterilerdir.

- Hafif biçimde sadık olan müşteriler: Sadakat programa üye olan, ancak teşviklerden sadece orta derecede etkilenen müşterilerdir.

- Ağır biçimde sadık olan müşteriler: Ödül programlarının sadık üyeleri olan müşterilerdir.

- Aşırı sadık olan müşteriler: Sadakat programları ile ilişki içerisinde olan (müşteriyi elde tutma) müşterilerdir.

Müşteri sadakat programları, müşteriyi elde tutmayı olumlu yönde etkileyen müşterinin mutluluğu için tasarlanmaktadır (Peter, 2010). Ayrıca, Peter'e göre; herhangi bir işletmenin aşağıdaki kurallara uyması durumunda, müşteri sadakat programlarının tasarımı başarılı olacaktır:

- Ürünü veya hizmeti yeniden satın alacak müşteriler edinin.

- Yeniden satın alma olasılığı düşük olan müşteriler için pazarlama harcamalarını sınırlandırın.

- Pazarlama programını, şimdi geri satın alan ancak henüz ikinci kez satın almayacak müşterilere odaklayın.

Dowling ve Uncless (1997), devamlı ve sadık müşteriler için müşteri değerlendirmesi, müşteri ödüllendirme ve müşteri ortaklığ1 gibi sadakat programlarından bahsetti. Bu programlar, müşterilere potansiyel hizmetlerin ödüllerini seçme konusunda bazı haklar veren farklı bağlılık programı türlerinden bazılarıdır. Müşterilerin iş birliği içerisinde olması için karşılıklı faydalarına dayalı olarak kısa ve uzun süreli ilişkiler yapılandırılmalıdır (Gomez vd., 2006). Bu durum, konaklama işletmelerinde, otelcilik pazarındaki rekabet seviyesini artıracaktır (Liu, 2007). Bu bağlamda, iyileştirilmiş müşteri sadakati programları, müşterileri şirket içinde tutacak ve müşteri memnuniyetini artıracak ve müşteriyi elde tutmayı olumlu yönde etkileyecektir (Rashid vd., 2015; Verhoef, 2003). Bunun yanında, bu programlara artan ilginin temelinde, pazarlama yöneticileri arasında müşterilerinin 
sadakati konusunda yaygın olarak kullanılan bazı inançlar bulunmasıdır (Dowling ve Uncles, 1997). Hughes (2003), sadakat programlarının amaçlarını şu şekilde sıralamaktadır: Müşteri değer gelişimi, sektör müşterilerinin getirisini artıracaktır. Müşteri değerini ve memnuniyetini artırmak şirketler için çok önemlidir, çünkü işletmeler müşteriye yönelik yatırım yaparken memnuniyet en önemli faktörlerden biridir. İşletmeler satış sonrası hizmetleri geliştirmek için ciddi bir adım oluşturmalı ve müşteri sadakat programı oluşturmak için müşteri sadakat programlarının benzer çalışmalarını inceleyip, distribütörlere odaklanmalıdır.

\subsection{Sadakat Programlarının Otel İşletmelerine Etkisi}

Çağdaş pazarlama trendlerinin bazı yönlerini keşfetme çabası, özellikle sadakat programlarını teşvik etmek için otel sektörünün benimsenmesine ve bunların müşteriyi tutma üzerindeki etkilerinin boyutuna dayanmaktadır (Oyman, 2002). Sadakat programlarının otel işletmelerindeki önemi günden güne artmaktadır ve giderek daha fazla müşteriyi bu programlarla elde tutma becerisi önem kazanmaktadır (Selvi ve Ercan, 2006). Sadakat programları, beş yıldızlı oteller, resort oteller, bungalovlar ve hatta en küçük butik oteller için her büyüklükteki oteller için tasarlanabilmektedir. İstatiksellere bakıldığında, Kemerli Konak Boutique Hotel gezginlerin seçim ödülü booking.com'da 9,5 puan alarak sadakat programları uygulayan bazı beş yıldızlı otellerden daha iyi bir başarı oranına sahip olduğu görülmüştür. Herhangi bir otelin müşteriye kaç oda sunduğundan ziyade, benzersiz bir sadakat programı uygulamak müşterilerin rezervasyon kararlarını etkileyecek, tekrar müşterileri teşvik edecek, oteller en çok fayda sağlaya müşterileri memnun edecektir (Palmer vd., 2010; Ramaseshan vd., 2008). Dünyada otel sadakat programlarını uygulayan bazı oteller yer almaktadır: Inter Continental, Best Western and Marriot Otels Ödülleri; Hilton Honors; Hyatt Gold Passport, Accor A-club (Kamacıŏlu, 2012). Merit International Hotel Group, Kuzey Kıbrıs'ın en popüler otel markalarından biri olan Girne' de sadakat programını uygulamaktadır. Merit Royal Hotel, müşterilerine, şirketlerin fotoğraflarını sosyal medyada paylaşmaya iten daha fazla puan kazandırıp ve bazı web sitelerini tavsiye edip, sunmaktadır. Bu bağlamda, oteller bir resim paylaşıp, herkes arkadaşlarını, akrabalarına etiketleyip, otellerin reklamlarını duyurursa, şanslı olan müşterilerin seçilmesiyle onlara bazı ödüller 
sunacağı duyurusunu yapmaktadır. Sosyal medyada Merit Hotel ve Colony Hotel bu paylaşım yöntemini, şirketin müşteriyle birlikte kullanmakta ve internetteki puanlarını artırmaya çalışmaktadır. Günümüzde internet üzerinden sosyal medya en önemli reklam unsuru haline geldiğinden dolayı, kolay bir şekilde ucuz yöntemle çok daha fazla insana ulaşmak otellere avantaj sağlamaktadır (Yılmaz, 2016). Bazı oteller, müşterilerin tarihsel ve sadakat verileri istatistiklerini ve sayılarını sistemlerinde takip etmektedir (Fidelio veya Elektra Otelciler Programı). Bu oteller, sadık müşterileri için özel indirim yapmakta ve yüksek hizmet standartları ile hizmet sunmaktadırlar (Özgür ve Günaydın, 2010; Özgen, 2013). Örnek verecek olursak: Bazı oteller (Merit Hotel ve Colony Hotel), müşteriler herhangi bir hizmet siparişi vermeden önce bazı içecekler, yemekler veya başka bir hizmet (bazen ödeme yapmadan) sunmaya çalışır. Bu tür faaliyetler, müşteri memnuniyetini, sadık misafir sayısını arttırır ve müşteriyi elde tutmayı sağlar. Otellerin müşterilerine verdiği değeri gösterir ve onların programdan memnun kalmasını sağlar. Başka bir perspektiften bakıldığında, birçok otel işletmeleri, özel müşterilerine değerli olduklarını göstermek için bazı müşteri kartları (platin, altın ve gümüş) veya kimlikleri sağlamaktadır. Üyelik kartları, müşterilerin özel ilgiyi hak ettiklerini belirtmeleri için hızlı ve etkili bir yoldur (Dowling ve Uncles, 1997). Bu müşteri kartları, casinolardaki, canlı oyunlar veya makine oyunları ile müşterilere bonus puanlar sağlayarak onları mutlu etmektedir. Bunun yanında, bazı ücretsiz oyunlar veya yiyecek/içecek bölümlerinde ücretsiz servisler, ücretsiz mesaj veya müşterilere sunulan diğer hizmetlerde bu kart sayesinde sağlanmaktadır (Çati ve Koçoğlu, 2008). Müşteri sadakat programı ile yapılan bu tür aktiviteler, müşterilerin memnuniyetini olumlu yönde etkileyecek ve sadık müşteri potansiyelini sağlayarak, onların otelde kalmasını sağlayacaktır. 
Tablo 1. Sadakat Programla ilgili Seçilen Çalışmaların Önemli Bulguları

\begin{tabular}{|c|c|c|c|c|c|}
\hline & Makale Bilgileri & $\begin{array}{c}\text { Sadakat } \\
\text { Programlarının } \\
\text { Adı / Üyelik } \\
\text { Türü }\end{array}$ & Yarar Türleri & Hedef Grup & $\begin{array}{c}\text { Sadakat } \\
\text { Programlarının } \\
\text { Müşteri Sadakati } \\
\text { Oluşturmaya Etkisi }\end{array}$ \\
\hline 1 & $\begin{array}{l}\text { Bowen, J.T. \& } \\
\text { Shoemaker, S. } \\
\text { (1998): Loyalty: A } \\
\text { Strategic } \\
\text { Commitment }\end{array}$ & $\begin{array}{l}\text { Ödül Kartları } \\
\text { Açık üyelik }\end{array}$ & $\begin{array}{l}\text { Bonus Puanı } \\
\text { İndirim } \\
\text { Ücretsiz satın } \\
\text { alma }\end{array}$ & $\begin{array}{l}\text { Yüksek gelire } \\
\text { sahip iş } \\
\text { seyahati } \\
\text { yapanlar }\end{array}$ & $\begin{array}{l}\text { Konukların çoğu } \\
\text { sunulan sadakat } \\
\text { programlarından } \\
\text { dolayı otele sadıktır. }\end{array}$ \\
\hline 2 & $\begin{array}{l}\text { McCleary, K.W. \& } \\
\text { Weaver, P.A. } \\
\text { (1991): Are } \\
\text { Frequent- Guest } \\
\text { Programs } \\
\text { Effective? }\end{array}$ & $\begin{array}{l}\text { Devamlı } \\
\text { Müşteri } \\
\text { Programı } \\
\text { Açık Üyelik }\end{array}$ & $\begin{array}{l}\text { Bonus Puanı } \\
\text { İndirim } \\
\text { Ücretsiz satın } \\
\text { alma }\end{array}$ & $\begin{array}{l}\text { Yüksek gelire } \\
\text { sahip yönetici } \\
\text { statüde iş } \\
\text { seyahati } \\
\text { yapanlar }\end{array}$ & $\begin{array}{l}\text { Sunulan sadakat } \\
\text { programları } \\
\text { olmamasına rağmen } \\
\text { müşteriler sadık } \\
\text { kalmaktadır }\end{array}$ \\
\hline 3 & $\begin{array}{l}\text { Toh, R.S., Rivers, } \\
\text { M. \& Withiam, G. } \\
\text { (1991): Frequent } \\
\text { Guest Programs: } \\
\text { Do They Fly? }\end{array}$ & $\begin{array}{l}\text { Devamlı } \\
\text { Müşteri } \\
\text { Programı } \\
\text { Açık Üyelik }\end{array}$ & $\begin{array}{l}\text { Bonus Puanı } \\
\text { İndirim } \\
\text { Ücretsiz satın } \\
\text { alma }\end{array}$ & $\begin{array}{l}\text { Yüksek gelire } \\
\text { sahip iş } \\
\text { seyahati } \\
\text { yapanlar }\end{array}$ & $\begin{array}{l}\text { Müşteriler } \\
\text { programdan dolayı } \\
\text { otelde kalmazlar. }\end{array}$ \\
\hline 4 & $\begin{array}{l}\text { Mc. Ilroy, A. \& } \\
\text { Barnett, S. (2000): } \\
\text { Building Customer } \\
\text { Relationship: Do } \\
\text { Discount Cards } \\
\text { Work? }\end{array}$ & $\begin{array}{l}\text { Altın Card } \\
\text { Sinırlı Üyelik }\end{array}$ & & $\begin{array}{l}\text { Otel } \\
\text { müşterileri } \\
\text { (çoğunlukla } \\
\text { yeni } \\
\text { müşteriler) } \\
\\
\text { Orta gelirli } \\
\text { yerel halk }\end{array}$ & $\begin{array}{l}\text { İndirim kartının } \\
\text { müşteri sadakatini } \\
\text { artırdığı } \\
\text { görülmemektedir. } \\
\text { Müşterilerin } \\
\text { kartlarının süresi } \\
\text { dolmuşsa tekrar satin } \\
\text { almazlar (programa } \\
\text { üyelikleri bitmiş } \\
\text { demektir). }\end{array}$ \\
\hline 5 & $\begin{array}{l}\text { Toh, R.S., Hu, M.Y. } \\
\text { \& Withiam, G. } \\
\text { (1991): Service: The } \\
\text { Key to Frequent } \\
\text { Guest Programs }\end{array}$ & $\begin{array}{l}\text { Devamlı } \\
\text { Müşteri } \\
\text { Programı } \\
\text { Açık Üyelik }\end{array}$ & $\begin{array}{l}\text { Bonus Puanı } \\
\text { İndirim } \\
\text { Ücretsiz satın } \\
\text { alma }\end{array}$ & $\begin{array}{l}\text { Yüksek gelire } \\
\text { sahip iş } \\
\text { seyahati } \\
\text { yapanlar } \\
\text { Birden çok } \\
\text { sadakat } \\
\text { programına } \\
\text { bağlı olanlar }\end{array}$ & $\begin{array}{l}\text { Müşterilerin otele } \\
\text { değil programlara } \\
\text { sadık oldukları } \\
\text { görülmektedir. }\end{array}$ \\
\hline
\end{tabular}

Kaynak: Wijaya, 2005: s. 27

Tablo 1'de görüldüğü üzere, çeşitli sadakat programları ve her çalışmanın müşteri sadakati üzerindeki etkisine kısa bir genel bakış gösterilmektedir. Yukarıdaki tüm çalışmalar incelendiğinde, her sadakat programlarının müşteri sadakatini artırma üzerinde önemli bir etkiye sahip olmadığı görülmektedir. Bazı çalışmalarda; 
müşteriler, sunulan programlardan dolayı şirketlere sadıktır. Bazı çalışmalarda ise programa ait olmalarına ve programdan bonus puan veya indirim almalarına rağmen, sadakat programını ve programın sağladığı faydaları umursamıyorlar. Bunun yerine, otellerin müşteri sadakatlerini ve memnuniyeti artırmanın hizmet kalitesi gibi diğer faktörler tarafından oluşturulduğu dikkate alınmıştır.

\subsection{Araştırmanın Hipotezleri ve Modeli}

Araştırmanın amacına uygun olarak, aşağıdaki hipotezler belirlenmiş, Şekil 1'deki araştırmanın modeli yaratılmıştır.

H1: Sadakat programlarının müşteriyi elde tutma üzerinde anlamlı bir etkisi vardır.

H1a: Müşteri sadakat programlarından memnuniyet ile müşteriyi elde tutma arasında anlamlı bir ilişki vardır.

H1b: Müşteri sadakat programlarından güven ile müşteriyi elde tutma arasında anlamlı bir ilişki vardır.

H2: Otel işletmelerde müşteri memnuniyeti sağlama ile müşteriyi elde tutma arasında anlamlı bir ilişki vardır.

H3: Müşteri sadakati ile müşteriyi elde tutma arasında anlamlı bir ilişki vardır.

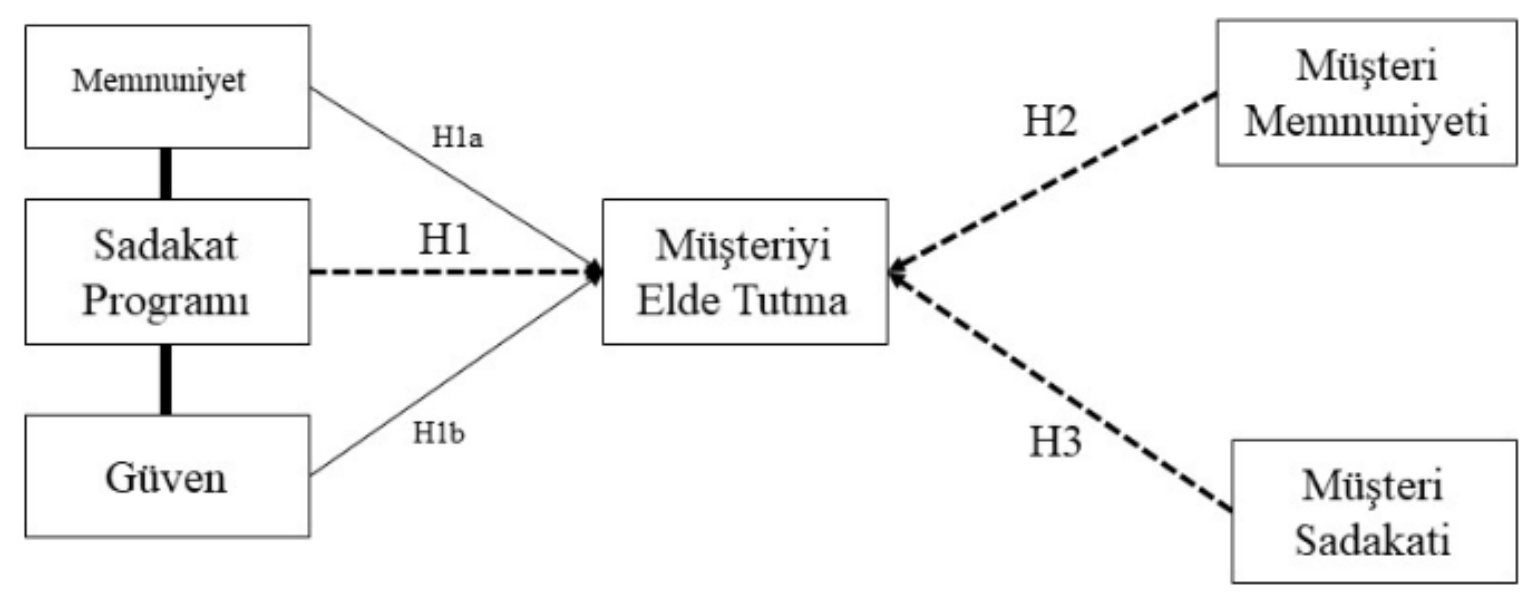

Şekil 1. Araştırma Modeli 


\section{YÖNTEM}

$\mathrm{Bu}$ araştırma, Girne bölgesinde faaliyet gösteren 5 yıldızlı otelde konaklayan müşterilere yönelik tesadüfü olmayan örnekleme tekniğinden kolayda örnekleme yöntemi kullanılarak anket uygulaması ile gerçekleştirilmiştir. Bu yöntemin seçilmesinin amacı, en basit ve sık kullanılan örnekleme yöntemi olması ve en kolay, hızlı ve ekonomik bir şekilde toplanmasından dolayıdır (Özdemir, 2008; Haşıloğlu, Baran ve Aydın, 2015). Kuzey Kibrıs'ta toplam 153 otel bulunmakta, bunlardan 22 tanesi 5 yıldızlı otel grubundadır. Araştırma evrenini iyi temsil edeceği düşünülmesinden dolayı, mümkün olduğunca sosyo-kültürel ve ekonomik düzeyde bilgiye sahip katılımcıya ulaşmaya çalışılmıştır. Örneklem büyüklüğünü hesaplamak için \%95 güven aralığı, \%5 güven düzeyi ve 2019 yılında Haziran ile Eylül arasında Kuzey Kıbrıs'a gelen toplam 653.671 turist sayısı dikkate alınarak örneklem büyüklüğü 450 olarak kararlaştırılmıştır (Turizm Planlama Dairesi, 2019). Araştırma verileri, 2019 yılında toplandığı bu çalışmada için etik kurul izni belgesi gerekmemektedir. Araştırmacı tarafından, 12 otele yönelik toplam 500 anket dağıtılmış, 450 anket toplanmış ancak 360 anket değerlendirmeye alınıp, analizi yapılmıştır. Değerlendirmeye alınan anketlerin cevaplama oranı \%72 olarak görülmüştür. Araştırmanın geçerliliğini ve güvenirliğini daha da artırmak için araştırmada bulunan eksik anketler ve araştırmacıların cevaplayış hataları nedeniyle 90 anket analize dahil edilmemiştir. Söz konusu evreni temsil edecek örneklem büyüklüğünün belirlenmesinde $n=N t 2 p q / d 2(N-1)+t 2 p q$ formülü kullanılmış ve aşağıda gösterilmiştir (Gümüş,2014).

$$
\begin{aligned}
& \text { n: } 653.671 \times(1,96)^{2} \times(0,5) \times(0,5) /(0,05)^{2} \times(653.671-1)+(1,96) 2 \times(0,5) \times(0,5) \\
& n=458,800 \approx 458^{\prime} \text { dir. }
\end{aligned}
$$

Anket, 2 bölümden oluşmaktadır. Birinci kısımda araştırmaya katılan kişilere yönelik demografik sorular yer almaktadır. İkinci kısım ise 4 gruptan oluşmakta, sorular araştırma amacına ve konusuna uygun olması bakımından, önceden yapılan çalışmalardan sentezlenerek yeniden oluşturulmuştur. 5'li likert tipi (1: Kesinlikle Katılmiyorum, 2: Katılmiyorum, 3: Kararsızım, 4: Katıliyorum, 5: Kesinlikle Katılıyorum) ölçekle hazırlanan toplamda 31 soru bulunmaktadır. İlk grupta, De Wulf 
vd. (2001)'nın, 4 sorudan oluşan sadakat programı memnuniyeti çalışmasına ve Molhotra vd. (2004)'nın, 5 sorudan oluşan sadakat programına güven yönelik toplam da 9 soru yer almaktadır. İkinci grupta, müşteri memnuniyetini belirlemeye yönelik 4 soruya yer verilmiştir. 1. ve 2. soru Oliver (1999, 1981) ve Hellier vd. (2003) çalışmalarından, 3 ve 4. soru ise Yıldız'ın, (2013) çalışmasından yararlanılarak ölçeğe eklenmiştir. Üçüncü grupta, müşteri sadakatini belirlemeye yönelik sorulara yer verilmiştir. Narayandas (1996), Hellier vd. (2003), Aydın ve Özer (2005), Küçükergin (2012) ve Erk (2009), tarafından yapılan çalışmalardaki ölçeklerin sentezi yapılarak araştırma sorularına eklenmiştir. Dördüncü grupta ise, Gümüş (2014), çalışmasından faydalanarak 10 sorudan oluşan müşteriyi elde tutma ölçeğine yer verilmiştir. Anketten elde edilen tüm veriler istatiksel programlardan SPSS 22. kullanılarak analiz edilmiştir.

\section{BULGULAR}

Araştırmaya katılan kişilerin demografik bilgileri Tablo 1 de incelendiğinde, araştırmaya katılan 360 kişiden \%57,0'ü erkek, \%43,0'ü ise kadın katılımcıdır. Bunun yanında, katılımcıların yaş gruplarına göre dağılımları incelendiğinde; \%2,7'si 18 ile 20 yaş arsı, \%16,1'i, 21-30 yaş arası, \%34,8'i 31-40 yaş arası ve \%46,4'ü ise 41 ve üstü olduğu görülmektedir. Bundan başka, katılımcıların eğitim düzeyleri incelendiğinde; \%9,4'ü ilköğretim, \%14,7'si lise, \%24,2'si ön lisans, \%42,0'1 lisans ve \%9,7'si de lisans üstü mezun olduğu tablo da görülmektedir. Katılımcıların meslek gruplarına göre dağılımları incelendiğinde, \%21,6'sı kamu da \%28,3'ü özel sektörde çalıştığ1 görülmüştür. Ayrıca, \%16,7'si iş adamı, \%20,3'ü emekli, \%2,8'i öğrenci ve \%10,3'ü diğer meslek grubunda yer almaktadır. Son olarak, araştırmaya katılan 360 kişinin gelir düzeyleri incelendiğinde, \%1,9'u 1000-2000 arası, \%23,1'i 2001-3000 arası, \%43,3'ü 3001-5000 arası ve \%31,7'si ise 5000 ve üzeri gelir grubunda yer aldığı tablo 2 detaylı bir şekilde görülmektedir. 
Tablo 2. Demografik Bilgiler

\begin{tabular}{|c|c|c|c|}
\hline Değişkenler & & & \\
\hline & & $(\mathrm{N})$ & Oran $\%$ \\
\hline \multirow[t]{2}{*}{ Cinsiyet } & Erkek & 205 & 57,0 \\
\hline & Kadın & 155 & 43,0 \\
\hline \multirow[t]{4}{*}{ Yaş } & $18-20$ & 10 & 2,7 \\
\hline & $21-30$ & 58 & 16,1 \\
\hline & $31-40$ & 125 & 34,8 \\
\hline & 41 ve üzeri & 167 & 46,4 \\
\hline \multirow{7}{*}{ Eğitim Durumu } & & & \\
\hline & İlköğretim & 34 & 9,4 \\
\hline & Lise & 53 & 14,7 \\
\hline & Ön lisans & 87 & 24,2 \\
\hline & Lisans & 151 & 42,0 \\
\hline & Lisansüstü & 35 & $x$ \\
\hline & & $x_{2}$ & +2 \\
\hline \multirow[t]{6}{*}{ Meslek } & Kamu & 78 & $x=$ \\
\hline & Özel Sektör & 102 & 28,3 \\
\hline & İş adamı & 60 & 16,7 \\
\hline & Emekli & 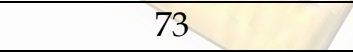 & 20,3 \\
\hline & Öğrenci & + & 2,8 \\
\hline & Diğer & 37 & 10,3 \\
\hline \multirow[t]{5}{*}{ Gelir Durumu } & $1000-2000$ & 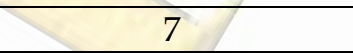 & 1,9 \\
\hline & $2001-3000$ & 83 & 23,1 \\
\hline & $3001-5000$ & 156 & 43,3 \\
\hline & 5001 ve üzeri & 114 & 31,7 \\
\hline & 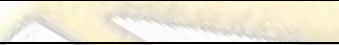 & 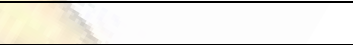 & \\
\hline Toplam & 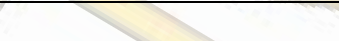 & 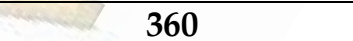 & 100 \\
\hline
\end{tabular}

Bu çalışmada, veri kümesinde tutarlı olan soruları organize etmek ve çalışmayı yönetilebilir kılmak için, veri kümesinin faktör analizi uygun olup olmadığını belirlemek için Kaiser Meyer Olkin (KMO) ve Barlett testi yapılmış ve Varimax yöntemi kullanılmıştır. Pallant ve Manual (2010), KMO değerinin minimum 0.6 olması gerektiğini önermektedir. Tablo 3'de görüldüğü üzere, Sadakat program ölçeğinin KMO değeri 0,798 düzeyinde ve Barlett testi ise $p=0.000<0.05$ düzeyinde anlamlı bulunmuştur. Tablo 3 'te görüldüğü gibi, özdeğeri 1'den ve faktör yükü 0,500 den büyük sadakat program memnuniyeti ve güveni olmak üzere toplam 9 maddeden oluşan faktör elde edildiğinden dolayı ölçek çıkarılmamıştır. Sadakat programına ölçeğinin 9 maddesinin toplam varyansı \% 43,925, özdeğer 5,185 ve Cronbach alfa değeri $a=0,835$ olarak bulunmuştur. Bu sonuçlara göre; otellerin sadakat program uygulamasının uygun veri setine ve değerlerine sahip olduğu görülmüştür. 
Tablo 3. Sadakat Programı Faktör Analizi

\begin{tabular}{|c|c|c|}
\hline & & $\begin{array}{l}\text { Faktör } \\
\text { Yükleri }\end{array}$ \\
\hline \multirow{11}{*}{$\begin{array}{c}\text { Müssteri Sadakat } \\
\text { Programı } \\
\text { (N=360; Faktör Yükü } \\
\geq 0.50, a=0,835 ; \\
\text { Bartlett's Test of } \\
\text { Sphericity=2749,238; } \\
\text { p=0.000; } \\
\text { KMO=0,798; } \\
\text { Toplam Varyans } \\
=\% 43,925 ; \\
\text { Öz değer }=5,185\end{array}$} & Sadakat Programina Memnuniyet & 0,576 \\
\hline & $\begin{array}{l}\text { S1. Bu programa katılmaya karar verdiğim dolayı iyi bir seçim } \\
\text { yaptım. }\end{array}$ & \\
\hline & S2. Genel açıdan, bu programı değerlendirmem iyidir. & 0,688 \\
\hline & $\begin{array}{l}\text { S3. Bu programin bir üyesi olarak aldığım avantajlar } \\
\text { beklentilerimi karşıllyor. }\end{array}$ & 0,716 \\
\hline & S4. Sonuçta, ben bu programdan memnunum. & 0,597 \\
\hline & Sadakat Programına Güven & \\
\hline & $\begin{array}{l}\text { S1. Bu sadakat programının kişisel bilgilerimi kullanmasına } \\
\text { güveniyorum. }\end{array}$ & 0,698 \\
\hline & $\begin{array}{l}\text { S2. Bu sadakat programı tarafımdan sağlanan uygulama kişisel } \\
\text { bilgilerle ilgili gerçeği ve tam vaatlerini yansıtmaktadır. }\end{array}$ & 0,714 \\
\hline & $\begin{array}{l}\text { S3. Bu sadakat programını kişisel bilgilerimi kullanrken } \\
\text { çıkarlarımı göz önünde bulunduracağına inanıyorum. }\end{array}$ & 0,642 \\
\hline & $\begin{array}{l}\text { S4. Genel olarak, bu sadakat programı kişisel bilgilerin } \\
\text { kullanımı konusunda öngörülebilir ve tutarlıdır. }\end{array}$ & 0,759 \\
\hline & $\begin{array}{l}\text { S5. Bu sadakat programı, müşterilerinin sağlayacağı kişisel } \\
\text { bilgileri kullanma konusunda her zaman dürüsttür. }\end{array}$ & 0,612 \\
\hline
\end{tabular}

Tablo 4' de görüldüğü üzere, müşteri memnuniyeti, sadakati ve müşteriyi elde tutma ölçeklerinin faktör analizi incelenmiştir. Müşteri memnuniyetinin KMO değeri 0,898, müşteri sadakati 0,825 ve müşteriyi elde tutma 0,758 değerlerine sahip olduğu ve Barlett testlerin ise $p=0.000<0.05$ düzeyinde anlamlı olduğu görülmüştür. Bunun yanında, müşteri memnuniyeti ölçeğinin 4 maddesinin toplam varyansı \% 34,951, özdeğeri 4,165 ve Cronbach alfa değeri ise $\alpha=0,875$ olarak bulunmuştur. Müşteri sadakati ölçeğinin 8 maddesinin toplam varyansı \%25,755, özdeğeri 3,159 ve Cranbach alfa değeri 0,898 olduğu görülmüştür. Son olarak, 10 maddeden oluşan müşteriyi elde tutma ölçeğinin faktör analizi incelendiğinde, toplam varyansı 13,522, özdeğeri 1,875 ve Cranbach alfa değerinin 0,795 değerinde olduğu yapılan analiz neticesinde görülmektedir. Fakör yükleri 0,500 değerinden yüksek olmasından dolayı ölçek çıkarılmamıştır. Analiz sonuçlarına göre, ölçeklerinin iyi düzeyde olduğu ve güvenilir veri setine sahip olduğu anlaşılmaktadır. 
Tablo 4. Müşteri Memnuniyeti /Sadakati ve Müşteriyi Elde Tutma Faktör Analizi

\begin{tabular}{|c|c|c|}
\hline & & $\begin{array}{l}\text { Faktör } \\
\text { Yükleri }\end{array}$ \\
\hline \multirow{5}{*}{$\begin{array}{c}\text { Müssteri Memnuniyeti } \\
\text { (N=360; Faktör Yükü } \\
\geq 0.50, a=0,875 ; \\
\text { Bartlett's Test of } \\
\text { Sphericity=2449,237; } \\
\text { p=0.000; KMO=0,898; } \\
\text { Toplam Varyans } \\
=\% 34,951 ; \text { Öz değer } \\
=4,165\end{array}$} & \multicolumn{2}{|l|}{ Müşteri Memnuniyeti } \\
\hline & $\begin{array}{l}\text { S1. Bu oteli tercih ederek doğru bir karar verdiğimi } \\
\text { düşünüyorum }\end{array}$ & 0,675 \\
\hline & S2. Bu otelin sunduğu hizmetlerden tamamiyla memnunum. & 0,637 \\
\hline & $\begin{array}{l}\text { S3. Bu otelde sunulan hizmetlerden dolayı, tekrar bu otelde } \\
\text { kalmayı düşünebilirim. }\end{array}$ & 0,686 \\
\hline & S4. Bu oteli eş, dost ve yakınlarıma tavsiye ederim. & 0,627 \\
\hline \multirow{9}{*}{$\begin{array}{c}\text { Müşteri Sadakati } \\
\text { (N=360; Faktör Yükü } \\
\geq 0.50, a=0,898 ; \\
\text { Bartlett's Test of } \\
\text { Sphericity=1747,125; } \\
\text { p=0.000; KMO=0,825; } \\
\text { Toplam Varyans } \\
=\% 25,755 ; \text { Öz değer } \\
=3,159\end{array}$} & Müşteri Sadakati & \\
\hline & S1. Bir sonraki seyahatimde yine bu otel ilk tercihim olacaktır. & 0,655 \\
\hline & $\begin{array}{l}\text { S2. Eş, dost ve yakınlarımı bu oteli tercih etmeleri konusunda } \\
\text { ikna etmeye çalışırım. }\end{array}$ & 0,623 \\
\hline & $\begin{array}{l}\text { S3. Önceki yıllara göre fiyat artırımı yapsa da bu oteli tercih } \\
\text { ederim. }\end{array}$ & 0,689 \\
\hline & $\begin{array}{l}\text { S4. Rakip oteller fiyat avantajı sağlasa da bu oteli tercih etmeye } \\
\text { devam edeceğim }\end{array}$ & 0,598 \\
\hline & S5. Bu otelin müşterisi olmaya devam edeceğim. & 0,699 \\
\hline & S6. Bu otel personelleri benim iyi bir arkadaşım gibileridir. & 0,575 \\
\hline & S7. Önerimi isteyen herkese bu oteli kesinlikle öneririm. & 0,618 \\
\hline & S8. Bu otel her zaman benim ilk tercihim olacaktır. & 0,545 \\
\hline & Müşteriyi Elde Tutma & \\
\hline \multirow{10}{*}{$\begin{array}{c}\text { Müşteri Elde Tutma } \\
\begin{array}{c}\text { (N=360; Faktör Yükü } \\
\geq 0.50, a=0,795 ; \\
\text { Bartlett's Test of } \\
\text { Sphericity=1019,102; } \\
\text { p=0.000; KMO=0,758; } \\
\text { Toplam Varyans } \\
=\% 13,522 ; \\
\text { Öz değer }=1,875\end{array}\end{array}$} & $\begin{array}{l}\text { S1. Üyelik programı kapsamında puan toplayabildiğim için } \\
\text { bu otelin sürekli müşterisiyim }\end{array}$ & 0,553 \\
\hline & $\begin{array}{l}\text { S2. Otel personellerinin bana ismimle hitap etmesi bu oteli } \\
\text { sürekli tercih etmemi sağlar. }\end{array}$ & 0,643 \\
\hline & $\begin{array}{l}\text { S3. } 7 / 24 \text { müşteri hizmetlerine ulaşabildiğim için her zaman bu } \\
\text { oteli tercih edeceğim }\end{array}$ & 0,588 \\
\hline & $\begin{array}{l}\text { S4. Bu otel öneri, istek ve şikâyetlerime hılı bir şekilde } \\
\text { çözüme kavuşturmasa da tercih etmeye devam edeceğim. }\end{array}$ & 0,616 \\
\hline & $\begin{array}{l}\text { S5. } \mathrm{Bu} \text { otelin yöneticileri özel günlerimde beni } \\
\text { hatırlamasından dolayı sürekli bu oteli tercih etmemi sağladı. }\end{array}$ & 0,595 \\
\hline & $\begin{array}{l}\text { S6. Bu otelin sağladığı hizmetler sayesinde kendimi değerli } \\
\text { hissediyorum. }\end{array}$ & 0,679 \\
\hline & $\begin{array}{l}\text { S7. Bu otelin Sosyal medya uygulamalarını (Facebook, } \\
\text { Twitter, Mobil uygulama) takip ediyorum }\end{array}$ & 0,658 \\
\hline & $\begin{array}{l}\text { S8. Bu otelin sürekli müşterisi olabilmem için bana özel } \\
\text { ayrıcalıklar tanınmasını beklerim. }\end{array}$ & 0,614 \\
\hline & $\begin{array}{l}\text { S9. Bu otelin sürekli müşterisi olmamdan dolayı bu otel beni } \\
\text { kaybetmeyi göze alamaz. }\end{array}$ & 0,649 \\
\hline & $\begin{array}{l}\text { S10.Bu otel çalışanlarından memnun olduğum için tercih } \\
\text { ediyorum. }\end{array}$ & 0,559 \\
\hline
\end{tabular}

SPSS'nin yardımıyla, müşteriyi elde tutmanın, sadakat programı, müşteri sadakati ve müşteri memnuniyeti üzerindeki etkisini belirlemek için çoklu regresyon analizi kullanıldı. Tablo 5'de görüldüğü üzere, bağımlı değişken müşteriyi elde tutma, 
bağımsız değişkenler müşteri sadakat programı ve değişkenleri, müşteri sadakati ve müşteri memnuniyeti olarak belirlenmiştir. Araştırmanın hipotezleri ile ilgili olarak şu sonuçlar bulunmuştur; bağımlı değişkenin bağımsız değişken üzerindeki etkileri sonucunda $\left(F(19,86)=p<0.05 ; R^{2}=0,23\right.$ değerleri bulunmuştur. $R^{2}$ değeri, bağıml değişkenin yüzde kaçında bağımsız değişken tarafından açıklandığını göstermektedir (Dursun ve Kocagöz, 2010). Araştırmada sadakat programlarının müşteriyi elde tutma üzerinde anlamlı bir etkisi olduğu hipotezi regresyon analizi sonucunda anlamlı bir etkisi olduğu görülmüştür $(\mathrm{t}=4.37, \mathrm{p}=0.000)$. Bunun yanında, sadakat programı değişkeni olan memnuniyet $(t=2.70, p=0.005)$ ve güven $(t=4.18, p=0.000)$ ölçeklerinin müşteriyi elde tutma arasında anlamlı bir ilişki düzeyi olduğu analiz sonucunda görülmüştür. Bundan başka, otel işletmelerde müşteri memnuniyeti sağlama ile müşteriyi elde tutma arasında anlamlı bir ilişki vardır hipotezi regresyon analizi sonucunda doğrulanmıştır ( $(=1.98, p=0.047)$. Son olarak, müşteri sadakati ile müşteriyi elde tutma arasında anlamlı bir ilişkisi hipotezi regresyon analizi sonucunda aralarında anlamlı bir ilişki olduğu görülmüştür $(t=2.75, p=0.006)$. Literatürde yer alan bazı çalışmalarda müşteri sadakati ile müşteriyi elde tutma arasındaki ilişki de desteklenmiştir. Rust ve Zahorik (1993)' e göre müşteriyi elde tutma ve müşteri sadakati arasında anlamlı bir ilişki vardır. Benzer şekilde, Hollowel (1996), müşteriyi elde tutma başarısı müşteri sadakatinin kazanılmasında etkili olduğunu ifade etmiştir.

Tablo 5. Çoklu Regresyon Analizi

\begin{tabular}{|c|c|c|c|c|c|c|c|c|}
\hline $\begin{array}{l}\text { Bă̆ımlı Değişken } \\
\text { Müşteriyi Elde } \\
\text { Etme }\end{array}$ & $\beta$ & S.E & $\begin{array}{c}\mathrm{t}- \\
\text { değeri }\end{array}$ & $\mathbf{P}$ & Beta & $\mathbf{F}$ & $\mathbf{R}$ & $\mathbf{R}^{2}$ \\
\hline Sabit & 5.393 & 0.112 & $15.71^{*}$ & 0.000 & - & & & \\
\hline $\begin{array}{l}\text { Sadakat Programı } \\
\text { (Memnuniyet) }\end{array}$ & 0.088 & 0.026 & $2.70^{* *}$ & 0.005 & 0.246 & & & \\
\hline $\begin{array}{l}\text { Sadakat Programı } \\
\text { (Güven) }\end{array}$ & 0.099 & 0.024 & $4.18^{*}$ & 0.000 & 0.249 & 19.86 & 0.48 & 0.23 \\
\hline $\begin{array}{l}\text { Müşteri } \\
\text { Memnuniyeti }\end{array}$ & 0.064 & 0.029 & $1.98^{* *}$ & 0.047 & 0.133 & & & \\
\hline Müşteri Sadakati & 0.085 & 0.030 & $2.75^{* *}$ & 0.006 & 0.150 & & & \\
\hline Sadakat Programı & 0.107 & 0.182 & $4.37^{*}$ & 0.000 & 0.298 & & & \\
\hline
\end{tabular}




\section{SONUÇ VE TARTIŞMA}

Son yıllarda gerek dünya genelinde gerek ise Kuzey Kıbrıs'ta, otel ve konaklama işletmeleri uzun vade kar hedeflerini belirlemek için fiyat rekabeti yaratmaktan ziyade müşteriyi elde tutma adına sadakat programları uygulayarak müşteriyi memnun etme ve müşteri sadakatini sağlama yönünde ciddi arayış içindedirler. Bundan dolayı, otel işletmecileri, müşteri memnuniyeti artırmak için çeşitli sadakat programları uygulamaktadır. Eğer otel işletmeleri müşterilerin beklentilerini karşılarsa ve müşteriyi tatmin ederse, müşteriyi elde tutması daha kolay şekilde olacaktır. Müşterinin memnuniyetlerini sağlamak isteyen otel işletmeleri, mevcut müşterilerine yoğunlaşmakla kalmayıp, potansiyel müşteri profiline sahip kişileri de memnun etmelidir. Böylelikle hem uyguladıkları sadakat programı hem de müşteri memnuniyeti sağlamak için verilen hizmetler sayesinde hem mevcut müşteriyi hem de potansiyel müşteriyi elde tutmak daha kolay olacaktır. Bu yüzden dolayı, otel işletmelerinde müşteri memnuniyeti, müşteri sadakati ve sadakat programlarının her geçen gün önemi ortaya çıkmakta ve rekabet ortamında önemli unsur olan otel işletmelerinin verdiği hizmet kalitesinin de önemi oldukça artmaktadır

Çalışmanın modeline uygun olarak, Girne'de faaliyet gösteren 12 beş yıldızlı otelin müşterilerine yönelik sadakat programları uygulayan yöneticilerin müşteriyi elde tutması için müşteri memnuniyeti ve sadakati arasındaki ilişkiler incelenmiş, çalışmanın amacı belirlenmiş ve hipotezleri oluşturulmuştur. Araştırmanın bulguları, müşteriyi elde tutmak için sadakat programlarının, doğrudan müşteri sadakatini etkileyen, müşteri memnuniyetini artırmanın en önemli aracı olduğunu göstermektedir. Sadakat programları, müşterinin memnuniyetini ve sadakatini etkiledikten sonra müşteriyi elde tutmayı sağlamaktadır. Farklı bir perspektiften bakıldığında, p değerinin \%5 den küçük olması nedeniyle bütün hipotezlerimiz kabul edilmiştir. Önceden yapılan literatür incelendiğinde araştırmamızın amacı doğrultusunda oluşturulan hipotezlerimizi desteklemektedir. Örnegin; Wijaya (2005) göre; uygulanan sadakat programları müşteri memnuniyetini artırır, sadık müşteri potansiyeline dönüştürür. Singh ve Khan'a (2012) göre ise, müşteriyi elde tutmak, işletmenin kârının en yüksek düzeye çıkmasını sağlayan faktördür, bu fakötürü sağlayan müşteri memnuniyeti ve sadakatidir. Barutçugil (2009) ve Lin ve Wu (2011) 
görüşüne göre ise, müşteri memnuniyeti, müşteri sadakati üzerinde olumlu bir etkiye sahiptir ve müşteriyi elde tutmaya neden olur. Bundan başka, Rashid vd. (2015) ve Verhoef (2003) ise iyileştirilmiş müşteri sadakati programlarının, müşterileri şirket içinde tutacaklarını, müşteri memnuniyetini artıracaklarını ve müşteriyi elde tutmayı olumlu yönde etkileyeceklerini ifade etmişlerdir.

Mevcut çalışma ile, şunlar önerilmektedir: Otel yöneticileri, müşteriyi elde tutmayı olumlu yönde etkileyebilmeleri için her türlü müşteri sadakat programına sahip olmalıdır. Daha cazip olabilmek için otel sektördeki işletmeler her zaman yeni ve farklı sadakat programlarına sahip olmalıdır. Otel yöneticileri hedef pazarlarını iyi bir şekilde belirlemelidir, çünkü müşterilerin tercihleri, özellikleri ve davranışları arasındaki farkları bölümlere ayırmalıdır. Sadakat programlarının farklılaşması, misafirlerin demografik özelliklerinin değişmesi ile uzun vadede daha fazla müşteri çekebilir. Sadakat programlarının geliştirilmesi ve iyileştirilmesi müşterilerin ihtiyaç ve gereksinimlerine uygun olmalıdır. Otel yöneticileri, müşterilerinin tavsiyelerini, yorumlarını ve şikayetlerini görüş ve programlarla ilgili önerilerini dinlemek için iyileştirilmiş bir geri bildirim sistemine sahip olmalıdır. Kuzey Kıbrıs'ta yer alan beş yıldızlı oteller, en etkili sadakat programlarını uygulayarak, anlık memnuniyet ödüllerini ve müşterilere faydalar içerdiğini hatırlamalıdır. Bu bağlamda, oteller, kendi otel türleri, varış noktaları ve hedef müşterileri için çalışan bir sadakat programı oluşturmalıdır. Oteller konuklara teşekkürlerini göstermelidir, çünkü müşteriler onlara başarı getirecektir.

Mevcut araştırma ile gelecekteki çalışmalar, geniş bir örneklem büyüklüğü ve Kuzey Kıbrıs'ta faaliyet gösteren bütün otel sektöründeki müşterilerin sadakatini etkileyen daha fazla değişken ile aynı şekilde çoğaltabilir. Aynı zamanda sadakat programlarının başarısını etkileyen diğer unsurlar dikkate alınabilir. Sadakat programlarının müşteri sadakati, müşteri memnuniyeti yaratıp yaratmadığı konusunda fikir birliği bazı çalışmalarda sağlanamadığı görüldüğünden, ilerideki çalışmalar daha zengin araştırma yapılarıyla bu görüşü desteklemelidir. Bunun yanında, otel işletmeleri müşteriye aidiyet duygusu yaşatan, işletmeyle duygusal bağları kuvvetlendiren ve müşteriyle iyi iletişimi sağlayan sadakat programlarına odaklanmalıdır. Ayrıca, bu araştırma, sadakat programlarının müşteriyi elde tutma ve 
müşteri memnuniyetini sağlama üzerinde önemli olduğunu ancak konaklama veya diğer sektörlerde çok fazla takdir edilmediğini ve dolayısıyla bu sektörlerdeki değerli müşteriler için nasıl daha iyi sadakat programları sunabileceği konusunda araştırmalar yapabileceği sonucuna da varmaktadır. 


\section{KAYNAKÇA}

Artuğer, S. (2011). Sık Uçan Yolcu Programlarının Müşteri Bağlılığı Üzerine Etkisi, Doktora Tezi, Adnan Menderes Üniversitesi, Sbe, Aydın.

Aydin, S., Özer, G. (2005), "The Analysis of Antecedents of Customer Loyalty in the Turkish Mobile Telecommination Market”, European Journal of Marketing, 39 (7/8), 910-925.

Bağcı, S. (2018). Müşteri Memnuniyeti Ve Müşteri Sadakatinin Hizmet Hatası Ve Müşteri Şikâyeti Kapsamında Incelenmesi, Düzce Üniversitesi Sosyal Bilimler Enstitüsü (Doctoral Dissertation, Yüksek Lisans Tezi, Düzce).

Bahar, O. And Kozak, M. (2005), International Tourism And Competition in Globalization Period. Ankara: Detayyayıncilık

Barutçugil, İ. (2009). Müşteri İlişkileri ve Satış Yönetimi. Birinci Baskı. İstanbul: Kariyer Yayıncılık.

Berman, B. (2006), “Developing An Effective Customer Loyalty Program, California Management Review",49(1), 123-148.

Çamlı, U. (2010). Yeniliğin Müşteri Sadakati Üzerindeki Etkileri; Turizm Sektörüne Yönelik Bir Araştırma. Yüksek Lisans Tezi, Ankara Üniversitesi Sosyal Bilimler Enstitüsü, Ankara.

Çati, K., \& Koçoğlu, C. M. (2008), “Müşteri Sadakati ile Müşteri Tatmini Arasındaki İlişkiyi Belirlemeye Yönelik Bir Araştırma”, Selcuk University Social Sciences Institute Journal, 19, 167-188.

Çoban, S. (2005), “Müşteri Sadakatinin Kazanılmasında Veri Tabanlı Pazarlamanın Kullanımı”, Erciyes Üniversitesi Sosyal Bilimler Enstitü Dergisi, 19, 295-307.

De Wulf, K., Odekerken-Schroder, G., \& Iacobucc1, D. (2001), “Investments İn Consumer Relationships: A Cross-Country And Cross-İndustry Exploration”, Journal Of Marketing, 65(4), 33-50.

Dowling, G. R., \& Uncles, M. (1997), “Do Customer Loyalty Programs Really Work?”, Sloan Management Review, 38, 71-82.

Dursun, Y. ve Kocagöz, E. (2010), “Yapisal Eşitlik Modellemesi ve Regresyon: Karşilaştirmali Bir Analiz", Erciyes Üniversitesi İktisadi ve İdari Bilimler Fakültesi Dergisi, (35), 1-17.

Erk, Ç. (2009). Müşteri İçin Değer Yaratma. Müşteri Sadakati Oluşum Süreci ve Şirket Performansına Etkileri Üzerine Araştırma. Edirne: Trakya Üniversitesi, Sosyal Bilimler Enstitüsü, Yayınlanmamış Yüksek Lisans Tezi. 
Gagliano, K.B., Hathcote, J. (1994), “Customer Expectations and Perceptions of Service Quality in Retail Apparel Specialty Stores", Journal of Services Marketing, 8(1), 60-69.

Giese, J. L., \& Cote, J. A. (2000), “Defining Consumer Satisfaction”, Academy of Marketing Science Review, 1(1), 1-22.

Gomez, B. G., Arranz, A. G., \& Cillán, J. G. (2006), “The Role Of Loyalty Programs in Behavioral and Affective Loyalty", Journal of Consumer Marketing, 23(7), 387-396.

Gopalkrishnan, J., Dr. Mishra, B. B., Dr. Gupta, V. K. \& Prof. Vetrivel, A. (2011), “The Impact of Service Quality and Customer Satisfaction on Customer Retention in the Indian Banking Industry: An Empirical Analysis". Research Journal of Social Science And Management, 1(3), 52-68.

Gronholdt, L., Martensen, A., \& Kristensen, K. (2000), “The Relationship Between Customer Satisfaction and Loyalty: Cross-Industry Differences", Total Quality Management, 11(4-6), 509-514.

Gümüş, C. (2014). Müşteri Memnuniyeti ve Müşteriyi Elde Tutmanın Müşteri Sadakatine Etkisi: Bir Araştırma. Ege Üniversitesi Sosyal Bilimler Enstitüsü Yayımlanmamış Doktora Tezi, İzmir.

Hallowell, R. (1996), “The Relationships of Customer Satisfaction, Customer Loyalty and Profitability International", Journal of Service Industry Management, 7(4), 27-42.

Haşıloğlu, S. B., Baran, T., \& Aydın, O. (2015), "Pazarlama araştırmalarındaki potansiyel problemlere yönelik bir araştırma: Kolayda örnekleme ve sıklık ifadeli ölçek maddeleri", Pamukkale İşletme ve Bilişim Yönetimi Dergisi, (1), 19-28.

Hellier, P.K., Geursen, G. M., Carr, R.A., And Rickard, J. A. (2003), “Customer Repurchase Intention: A General Structural Equation Model", European Journal of Marketing, 37 (11/12), 762-800.

Hennig-Thurau, T., \& Klee, A. (1997), "The Impact of Customer Satisfaction And Relationship Quality on Customer Retention: A Critical Reassessment and Model Development", Psychology \& Marketing, 14(8), 737-764.

Hughes, A. M. (2003). Customer Loyalty Solution. Mcgraw-Hill Professional Publishing.

Kahraman, Ç. A. T. I., Koçoğlu, Ö. G. C. M., \& Gelibolu, A. G. L. (2010), “Müşteri Beklentileri ile Müşteri Sadakati Arasındaki İlişki: Beş Yıldızlı Bir Otel Örneği", Çukurova Üniversitesi Sosyal Bilimler Enstitüsü Dergisi, 19(1), 429-446.

Kuzey Kıbrıs Türk Cumhuriyeti Turizm Bakanlığı (2019). Turizm Planlama Dairesi. Erişim Tarihi: 18.05.2020. http:/ / turizmplanlama.gov.ct.tr/TUR\%C4\%B0ZM\%C4\%B0STAT\%C4\%B0ST\%C4\%B0KLER\%C4\%B0. 
Kamacioğlu, A. (2012). Hotel Loyalty Programs. Erişim Tarihi: 10.02.2020. https://Www.Linkedin.Com/Pulse/İmportance-Hotel-Loyalty-Programs.

Küçükergin, K.G. (2012). Müşteri Sadakatinin Oluşum Sürecine Müşteri Memnuniyeti ve Ataletin Etkisi: Yiyecek- İçecek İşletmelerine Yönelik Bir Uygulama. (Yayınlanmamış Yüksek Lisans Tezi). Gazi Üniversitesi, Ankara.

Lacey, R., \& Sneath, J. Z. (2006), “Customer Loyalty Programs: Are They Fair To Consumers?”, Journal of Consumer Marketing, 23(7), 458-464.

Lee, J. J., Capella, M. L., Taylor, C. R., \& Gabler, C. B. (2014), “The Financial Impact of Loyalty Programs in the Hotel Industry: A Social Exchange Theory Perspective", Journal of Business Research, 67(10), 2139-2146.

Lin, J. S. C., \& Wu, C. Y., (2011), "The Role of Expected Future Use in Relationship Based Service Retention", Managing Service Quality, 21(5), 535-551.

Liu, Y. (2007), "The Long-Term Impact of Loyalty Programs on Consumer Purchase Behavior and Loyalty", Journal of Marketing, 71(4), 19-35.

Magatef, S. G., \& Tomalieh, E. F. (2015), “The İmpact Of Customer Loyalty Programs on Customer Retention", International Journal of Business and Social Science, 6(8), 78-93.

Malhotra, N. K., Kim, S. S., \& Agarwal, J. (2004), “Internet Users' Information Privacy Concerns (Iu1pc): The Construct, The Scale, And A Causal Model", Information Systems Research, 15(4), 336-355.

Narayandas, N. (1996). The Link between Customer Satisfaction and Customer Loyalty: An Empirical İnvestigation. Division of Research, Harvard Business School.

Nili, A., \& Keramati, A. (2012), “Customer Retention Programs of CRM And Customer Retention in EBanking", International Journal of E-Entrepreneurship and Innovation (Ijee1), 3(1), 18-32.

Nykıel, R. A. (2005). Hospitality Management Strategies, Upper Saddle River, New Jersey.

Odabaşı, Y. (2000). Satışta ve Pazarlamada Müşteri İlişkileri Yönetimi. İstanbul: Sistem Yayıncılık

Oliver, R. (1981), "Measurement and Evaluation of Satisfaction Processes in Retail Settings", Journal of Retailing, 57, 25-48.

Oliver, R. L. (1999), “Whence Consumer Loyalty”, Journal of Marketing, (63), 33-44. 
Onaran, B., Atıl Bulut, Z., \& Özmen, A. (2013). “Müşteri Değerinin, Müşteri Tatmini, Marka Sadakati ve Müşteri İlişkileri Yönetimi Performansı Üzerindeki Etkilerinin İncelenmesine Yönelik Bir Araştırma", Business \& Economics Research Journal, 4(2).

Oyman, M. (2002), “Müşteri Sadakati Sağlamada Sadakat Programlarının Önemi”, Kurgu Dergisi, 16, 169-185.

Özdemir, A. (2008). Yönetim Biliminde İleri Araştırma Yöntemleri ve Uygulamalar. Beta Yayınları, İstanbul.

Özgen, H. K. Ş. (2013), “Otel İşletmelerinde Müşteri Yönlülük Uygulamaları: Antalya İlindeki Beş Yıldızlı Oteller Örneği', Dokuz Eylül Üniversitesi İşletme Fakültesi Dergisi, 14(2), 109-126.

Özgür, Ö. \& Günaydın, Y. (2010), “Otel İşletmelerinde Müşteri Memnuniyeti ve Müşteri Sadakati İlişkisi: Dört Yıldızlı Otel İşletmelerinde Bir Uygulama", Dokuz Eylül Üniversitesi İşletme Fakültesi Dergisi, 11(2), 127-154.

Özkaya Kalkan, Y. (2002). Turizm Pazarlamasında Müşteri Tatmini ve Bir Araştırma. (Yayınlanmamış Yüksek Lisans Tezi). Marmara Üniversitesi, İstanbul.

Öztürk, Y., \& Seyhan, K. (2005). “Konaklama İşletmelerinde Sunulan Hizmet Kalitesinin Artırılmasında İş Gören Eğitiminin Yeri ve Önemi", Gazi Üniversitesi Ticaret ve Turizm Eğitim Fakültesi Dergisi, (1), 121-140.

Pallant, J., \& Manual, S. S. (2010). A Step By Step Guide To Data Analysis Using Spss. Berkshire Uk: Mcgraw-Hill Education.

Palmer, A., Mcmahon-Beattie, U., \& Beggs, R. (2000), “Influences on Loyalty Programme Effectiveness: A Conceptual Framework and Case Study Investigation", Journal of Strategic Marketing, 8(1), 47-66.

Peiguss (2012). 7 Customer Loyalty Programs that Actually Add Value. Erişim Tarihi: 30.02.2020. Http://Blog.Hubspot.Com/Blog/Tabid/6307/Bid/31990/7-Customer-Loyalty.

Peter, C. (2010). The 15 Business Benefits of A Loyalty Initiative. The Wise Marketer.

Pizam, A., \& Ellis, T. (1999), "Customer Satisfaction and its Measurement in Hospitality Enterprises", International Journal of Contemporary Hospitality Management, 11(7), 326-339.

Potter-Brotman, J. (1994), “The New Role of Service in Customer Retention”, Managing Service Quality: An International Journal, 4 (4), 53-56.

Ramaseshan, B., Evanschitzky, H., \& Johnston, M. (2008), Mediating Effect Of Program Loyalty on the Relationships between Value Perception and Relationship investment on Customer Loyalty. 
In Proceedings of Australian and New Zealand Marketing Academy Conference . University Of Western Sydney.

Rashid, I. M. A., Rani, M. J. A., Yusuf, B. N. M., \& Shaari, M. S. (2015), "The Impact of Service Quality and Customer Satisfaction on Customer's Loyalty: Evidence From Fast Food Restaurant of Malaysia", International Journal of Information, Business and Management, 7(4), 201.

Ray, S. (2015). Traditional Loyalty Programs-Broken?. Business Technology. Erişim Tarihi:05.03.2020. www. İtwire. Com/Business-İtnews/Business-Technology/İtemlist/User/11234-Rayshaw.

Reinartz, W., Krafft, M., \& Hoyer, W. D. (2004), “The Customer Relationship Management Process: Its Measurement And Impact on Performance", Journal of Marketing Research, 41(3), 293-305.

Roking (2005). Customer Retention Programs. Erişim Tarihi: 10.03.2020. www.Saleslobby.Com/Mag/0601/Ferk.Asp

Rust, R. T., \& Zahorik, A. J. (1993), "Customer Satisfaction, Customer Retention and Market Share", Journal of Retailing, 69 (2), 193-215.

Selnes, F. (1993), "An Examination of the Effect of Product Performance on Brand Reputation, Satisfaction and Loyalty”, European Journal of Marketing, 27(9), 19-35.

Selvi, M. S., \& Ercan, F. (2006), “Otel İşletmelerinde Müşteri Sadakatinin Değerlendirilmesi: İstanbul'daki Beş Yıldızlı Otel İşletmelerinde Bir Uygulama”, Balıkesir Üniversitesi Sosyal Bilimler Enstitüsü Dergisi, 9(15), 159-188.

Singh, R., \& Khan, I. A. (2012), "An Approach To Increase Customer Retention and Loyalty In B2c World", International Journal of Scientific and Research Publications, 2(6): 1-5.

Stathopoulou, A., \& Balabais, G. (2016), "The Effects of Loyalty Programs on Customer Satisfaction, Trust, and Loyalty Toward High-and Low-End Fashion Retailers"', Journal of Business Research, 69(12), 5801-5808.

Şahin, A., \& Şen, S. (2017), "Hizmet Kalitesinin Müşteri Memnuniyeti Üzerine Etkisi”, Journal of International Social Research, 10(52), 1177-1184.

Tu, Y., Wang, C., Chang, H. (2012), “Corporate Brand Image and Customer Satisfaction on Loyalty: An Empirical Study of Starbucks Coffee in Taiwan", Journal of Social and Development Sciences, 3(1), 2432.

Uncles, M., Ehrenberg, A., \& Hammond, K. (1995), “Patterns of Buyer Behavior: Regularities, Models, and Extensions". Marketing Science, 14(3_Supplement), G71-G78. 
Uyar, A. (2019), “Müşteri Memnuniyeti ile Müşteri Sadakati Arasındaki İlişkinin Yapısal Eşitlik Modeli ile İncelenmesi: Otomobil Kullanıcıları Üzerine Bir Uygulama", Elektronik Sosyal Bilimler Dergisi, 18(69), 41-57.

Valenzuela, F., \& Vásquez-Párraga, A. (2006), "Trust And Commitment As Mediating Variables in the Relationship Between Satisfaction and Hotel Guest Loyalty", Panorama Socioeconomico, 24(32), 18-23.

Verhoef, P. C. (2003), “Understanding The Effect of Customer Relationship Management Efforts on Customer Retention and Customer Share Development”. Journal of Marketing, 67(4), 30-45.

Wijaya, S. (2005), “The Effect of Loyalty Programs on Customer Loyalty in the Hospitality Industry", Journal Manajemen Perhotelan, 1(1), 24-31.

Wu, S. I., \& Chen, J. H. (2012), “Comparison Between Hotels and Motels Using Crm Effect Model-An Empirical Study in Taiwan”, International Journal of Hospitality Management, 31(4), 1254-1263.

Yıldız, Y. (2013). Hizmet İşletmelerinde Müşteri Memnuniyeti ve Müşteri Sadakati Etkileşiminin İncelenmesi, Sivas İlinde Bir Uygulama. (Yayınlanmamış Yüksek Lisans Tezi), Cumhuriyet Üniversitesi, Sivas.

Yılmaz, A. İ. (2016). Bir Rekabet Stratejisi Olarak Farklılaşma: Otel İşletmeleri Üzerine Bir Araştırma. (Yayınlanmamış Yüksek Lisans Tezi), Adnan Menderes Üniversitesi, Aydın.

Yi, Y., \& Jeon, H. (2003), “Effects of Loyalty Programs on Value Perception, Program Loyalty, and Brand Loyalty", Journal of the Academy of Marketing Science, 31(3), 229-240.

Zeithaml, V. A., Berry, L. L., \& Parasuraman, A. (1993), “The Nature and Determinants of Customer Expectations of Service", Journal of The Academy of Marketing Science, 21(1), 1-12. 